\title{
ANALYSIS OF DIFFICULTY LEVEL OF INFORMATION SYSTEM STUDENTS IN COMMUNICATING ENGLISH IN INDUSTRIAL ERA 4.0
}

\author{
Ratih Purwasih \\ STMIK Indonesia Padang \\ Rahimmulaily \\ STMIK Indonesia Padang
}

\begin{abstract}
Purpose of this study is to describe the difficulty level of information system students in communicating English. This study was descriptive quantitative research. The subjects in this study were 100 of second semester information system students and students who repeated (30 people) in 2017/2018 at STMIK Indonesia Padang. The study instrument used was a questionnaires and it were distributed to all research subjects. The processing of questionnaire data used the construct validity test which was supported by the SPSS application. The results of the data analysis of the study shows that the difficulty level of information systems students in communication is categorized at a fairly problematic level with an percentage index of 69\%. Therefore, the results of this study can be used as a reference for lecturers in designing learning modules and syllabus that matches with the level of students' ability so that they will be categorized as students who are able to compete in the industrial era 4.0 .
\end{abstract}

Keywords: communication difficulties, English, SPSS

Permalink: http://dx.doi.org/10.21831/jpv.v9i1.22761

Contact Ratih Purwasih ratihpurwasih254@gmail.com

STMIK Indonesia Padang, Jl. Khatib Sulaiman No.1, Lolong Belanti, Padang Utara, Kota Padang, Sumatera Barat 25136, Indonesia 


\section{INTRODUCTION}

Technology world competition in the industrial era 4.0 is currently felt by all universities, especially universities which are based on technology discipline. STMIK Indonesia is a college that produces students who are able to compete in the field of Information Systems. This field of science does not only require students to be able to make a system and analyze the system, but also supported by good communication skills

Industrial era 4.0 in the aspect of communication skill requires students not only to be able to communicate at the national level but also international so that the students are able to compete globally with the knowledge they have. One of the media in international communication uses English as the language of instruction. According to Rohida (2018), states that the industrial era 4.0 and globalization require outstanding human beings and professionals with a high work ethic who do not give up. Strict competition among countries will spur one of individual in the ability to communicate in English.

The sudents of STMIK Indonesia who have background in information systems study program that are closely related to the world of technology and the world of industry should also have supporting abilities in communicating English. However, the preliminary observation was found in the meeting of English 1 and 2 which obtained were not able to improve the ability of the students of STMIK Indonesia both oral and written. It can be seen in Figure 1.

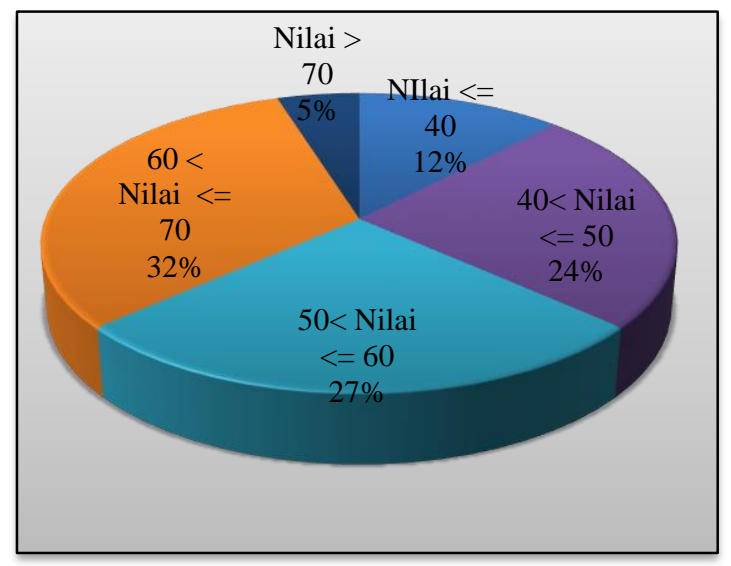

Figure 1. English Skill Averages of STMIK Indonesia Students
Based on Figure 1, the English skill averages of STMIK Indonesia students is varied, it can be categorized into several levels including low, medium and high. However, the category of low and medium are getting a quite high percentage. It illustrates that it is still difficult for students to communicate using English. Meanwhile, for students who have a computer background, have a very large opportunity in large national and international companies.

This study aims to obtain data on the descriptive quantitatively of difficulty level of English communication by students in Information Systems majors at STMIK Indonesia. The results to be achieved in this study is a valid percentage value to determine the level of difficulty of English communication skill which will have a positive impact in finding the method or design of teaching materials which can arranged and applied to students who are Non-English Department. Therefore, this study will discuss about "Analysis of difficulty level of information system students in communicating English industrial era 4.0". resarch are:

The related theory that is used in this

\section{English Communication Ability}

Communication ability is the ability to express thoughts, feelings, desires, through verbal communication or nonverbal communication to get understanding from others. Therefore, the ability to communicate has an impact on our understanding and that of others.

There are some definiton of communication have provided by the expert. According to (Zahroh \& Sudira, 2014) Communication skills are an ability to communicate effectively with others, using oral, written, graphical, and other non-verbal means such as expressions. Then, according to John R. Wenburg, William W. Wilmot, Kenneth K. Sereno and Edward M. Bodaken (Mulyana, 2008), there are three frameworks for understanding communication, namely communication as one-way action, communication as interaction, and communication as a transaction. Based on the classification of communication, the focus of communication taken in this study is communication as interaction. 


\section{English communication difficulties}

In the process of learning English, a student has a difficulty experiences in learning English as communication. These difficulties can cause a lack of maximum student learning outcomes in english subject. Several factors of student difficulties in communicating English include lack of vocabulary in English, difficulty in memorizing, diversified vocabularies pronunciation, fear of making mistakes, fear of being mocked by friends and lack of grammar knowledge (Megawati, 2016). This is also in line with the results of the study of Afisa (2015) which stated that the factors causing difficulties in speaking English were the number of frequencies of practice speaking English and psychology (in this case it could be said to be affective factors). Therefore, the difficulties of students in communicating English are categorized in several problems summarized in the Table 1.

Table 1. The Difficulties of Students in Communuicating English

\begin{tabular}{|c|c|}
\hline Difficulties 1 & $\begin{array}{l}\text { Difficulty in Diversified } \\
\text { Vocabularies Pronunciation }\end{array}$ \\
\hline Difficulties 2 & $\begin{array}{l}\text { Vocabulary Difficulty in } \\
\text { Mastering English Vocabularies }\end{array}$ \\
\hline Difficulties 3 & $\begin{array}{l}\text { Difficulty due to Fear of being } \\
\text { Mocked by Friends }\end{array}$ \\
\hline Difficulties 4 & $\begin{array}{l}\text { Difficulty Due to the Limited } \\
\text { Time to Learn }\end{array}$ \\
\hline Difficulties 5 & $\begin{array}{l}\text { Difficulty Due to Irrelevant } \\
\text { Learning Method }\end{array}$ \\
\hline Difficulties 6 & $\begin{array}{l}\text { Difficulty Due to Lack of Self- } \\
\text { Confidence }\end{array}$ \\
\hline Difficulties 7 & $\begin{array}{l}\text { Difficulty Due to Constraints By } \\
\text { Grammar When Arranging Words }\end{array}$ \\
\hline Difficulties 8 & $\begin{array}{l}\text { Difficulty Due to Lack of } \\
\text { Willingness in Learning English }\end{array}$ \\
\hline Difficulties 9 & Difficulty Due to Fast Bored \\
\hline
\end{tabular}

\section{Construct Validity}

Construct is a framework of a concept.Then, construct Validation is validity related to the ability of a measuring instrument in measuring the understanding of a concept that is measured. According to Jack R. Fraenkel (Siregar, 2017) construct validation (determination of construct validity) is the broadest of its coverage compared to other validations, because it involves many procedures, including content validation and criteria validation.

How to test construct validation. A research instrument is said to be valid, if: (1) Product moment correlation coefficient exceeds 0.3 ; (2) Product moment correlation coefficient> r-table $(\alpha ; n-2) n=$ number of samples; (3) Sig value $\leq \alpha$.

\section{Cronbach Alpha Technique Reliability Test}

This technique or formula can be used to determine whether a research instrument is reabel or not, if the answers given by respondents are in the form of scales, such as 1-3, 15 , and 1-7 or respondent's answers that interpret attitude ratings.

The criteria for a research instrument are said to be reabel by using this technique, if the reliability coefficient 『(r】_11)>0.6. Stages of reliability testing using the Cronbach alpha technique, namely: (1) determine the variance value of each question item; (2) determine the total variance value; (3) determine instrument reliability

\section{RESEARCH METHOD}

This study is quantitative with using descriptive, namely by describing the object of study at the moment based on the facts as they are then analyzed and interpreted.

The subjects in this study are 100 of second semester information system students and students who repeated (30 people) in repairing English courses in 2017/2018 at STMIK Indonesia Padang. Samples of this study are 60 of second semester students and 22 of repeat class. The sampling technique used in this study is probability sampling: proportional stratified sampling to the size of the proportion $\frac{85}{130}$.

Object of this study is the factors of difficulty in communicating English. The study instrument is in the form of a questionnaire which is developed based on relevant study references.

Analyzing the data (questionnaire) in this study conducted a validity test. This validity test uses construct validity. Construct validity is validity that is related to the ability of measuring tool in gauging the understanding of a concept which being measured (Siregar, 
2017). In addition to testing the validity of the questionnaire, the reliability test is also carried out using alpha cronbach technique as assisted count tool in testing the construct validity of the research team by using the SPSS version 16.0 application.

\section{RESULTS AND DISCUSSION}

\section{Test Validity}

The study of validity tests carried out on the amount of data as many as 85 respondents (students) by using the SPSS program software. The formula used in conducting the validity test is: $r_{\text {hitung }} \geq r_{\text {table }}$ then the item statement is valid.

The results of the difficulty validity test of 85 respondents (students), which each variable has $r_{\text {hitung }} \geq r_{\text {table }}$ or $r_{\text {hitung }} \geq$ 0.215 . Thus, it can be concluded that all data generated by the validity test are declared valid.

\section{Reliability Test}

Reliability test conducted to 85 respondents (students), following the result of reliability test to 85 respondents shows in the Table 2 .

Table 2. Test Results the Reliability

\begin{tabular}{ccc}
\hline Variable & $\begin{array}{c}\text { Value of Cronbach } \\
\text { alpha }\end{array}$ & Decision \\
\hline Difficulty & 0.726 & Reliable \\
\hline
\end{tabular}

Based on Table 2, it can be seen the results of a reliability test conducted to 85 respondents (students), which generates value of Cronbach alpha is 0.726 so that the collected data is declared reliable because the value of Cronbach alpha is greater from 0.6.

\section{Evaluation of Difficulty Level of Students in Communicating English.}

Evaluation of difficulty level of students in communicating English which is obtained from questionnaire is distributed to 85 of second semester students who take English courses 2 . The level of difficulty is categorized into 4 categories, namely very problematic, problematic, quite problematic and no problem. Very problematic category, if the answer score is $25 \%-43.53 \%$. Problematic, if the answer score is $43.82 \%-62.35 \%$. Quite problematic, if the answer score is $62.65 \%$ $81.18 \%$. No problem, if the answer score is $81.47 \%-100.00 \%$.

\section{Research Data Description}

\section{Difficulty in Diversified Vocabularies Pro- nunciation}

The result of data analysis on the level of difficulty in the pronunciation of various Vocabularies can be seen in the details on Table 3.

Table 3. Student Difficulty in Diversified Vocabularies Pronunciation

\begin{tabular}{llccc}
\hline No & Answer Options & $\begin{array}{c}\text { Fre- } \\
\text { quency }\end{array}$ & Value & $(\%)$ \\
\hline 1. & Very Problematic & 5 & 5 & 6 \\
2. & Problematic & 32 & 64 & 38 \\
3. & Quite Problematic & 41 & 123 & 48 \\
4. & No problem & 7 & 28 & 8 \\
& $\quad$ Total & 85 & 220 & 100 \\
\hline
\end{tabular}

Total value is $220=$ Quite Problematic Value percentage index 220: $340 \times 100 \%=$ $65 \%$

The results of data processing on Table 4.1 found the level of difficulty experienced by students in English vocabularies pronunciation is $65 \%$. This percentage is categorized as quite problematic. Therefore, it needs a fairly creative teaching method in the teaching and learning process in the classroom, one of which uses interactive video media.

According to Kustandi \& Sutjipto (2011), in teaching students about ways to use the "organs of speech" to speak words or sentences (pronunciation), then the video media will be more appropriate to use". The video is suitable for practicing pronunciation, besides displaying a recording or moving image, it also provides sound. The diagram above is the percentage of the number of students who have difficulty in pronunciation of vocabularies.

\section{Difficulty in Mastering English Vocabularies}

The result of data analysis of English difficulties related to the number of words that 
must be mastered can be seen in the details on Table 4.

Table 4. Percentage of Students who Experience Difficulty due to Mastering a lot of Vocabularies in English

\begin{tabular}{llccc}
\hline No & Answer Options & $\begin{array}{c}\text { Fre- } \\
\text { quency }\end{array}$ & Value & $(\%)$ \\
\hline 1. & Very Problematic & 4 & 4 & 5 \\
2. & Problematic & 37 & 74 & 43 \\
3. & Quite Problematic & 41 & 123 & 48 \\
4. & No problem & 3 & 12 & 4 \\
& $\quad$ Amount & 85 & 213 & 100 \\
\hline
\end{tabular}

Total value is $213=$ Quite Problematic Value percentage index 213: $340 \times 100 \%=$ $63 \%$

The results of data processing on Table 4.2 found the level of difficulty experienced by students is due to too many vocabularies which must be mastered in English at the percentage index is $63 \%$. This percentage is categorized as quite problematic, so it needs a solution to face this problem.

According to Nugroho, Nurkamto, \& Sulistyowati (2012) to improve vocabularies skill for students by using flash cards will be more appropriate to use. Flash cards are suitable for adding vocabulary because the presence of images, texts and symbols so that it attracts the students' attention, making students motivated and focused on learning vocabulary. This method can later be applied in the teaching methods at STMIK Indonesia Padang.

\section{Difficulty due to Fear of being Mocked by Friends}

The result of data analysis in English difficulty due to fear of being mocked by friends can be seen in the details on Table 5 .

The result of data processing on Table 5 found the level of difficulty experienced by students due to fear of being mocked by friends is at $81 \%$. It means that the percentage of this difficulty level is categorized as no problem. It shows that the mentality of students in facing the mockery of friends can still be overcome.
Table 5. Difficulty table due to Fear of Being Mocked by Friends

\begin{tabular}{llccc}
\hline No & Answer Options & $\begin{array}{c}\text { Frequ- } \\
\text { ency }\end{array}$ & Value & $(\%)$ \\
\hline 1. & Very Problematic & 5 & 5 & 6 \\
2. & Problematic & 11 & 22 & 13 \\
3. & Quite Problematic & 26 & 78 & 31 \\
4. & No problem & 43 & 172 & 50 \\
& $\quad$ Total & 85 & 277 & 100 \\
\hline
\end{tabular}

Total value is $277=$ No Problem

Value percentage index 277: $340 \times 100 \%=$ $81 \%$

\section{Difficulty Due to the Limited Time to Learn}

The result of data analysis in English difficulty due to the limited time to study can be seen in the details on Table 6.

Table 6. Difficulty Table Due to the Limited Time to Learn

\begin{tabular}{clccc}
\hline No Answer Options & $\begin{array}{c}\text { Fre- } \\
\text { quency }\end{array}$ & Value & $(\%)$ \\
\hline 1. & Very Problematic & 12 & 12 & 14 \\
2. & Problem & 26 & 52 & 31 \\
3. Quite Problematic & 31 & 93 & 36 \\
4. No problem & 16 & 64 & 19 \\
Total & 85 & 221 & 100 \\
\hline
\end{tabular}

Total value is $221=$ Quite problematic Value percentage index 221: $340 \times 100 \%=$ $65 \%$

The results of data processing Table 6 found the level of difficulty experienced by students due to limited time to learn is $65 \%$. The result of this percentage indicates that student' interest and motivation in learning which their background Non English department in improving their English communication skill is still low. This is because STMIK Indonesia has background in the information system study program. The students only focus on their knowledge so that there is a limited effort of students in upgrading the ability to communicate English in personal skills for students.

According to Nurhidayati (2016) "To take the time to study, students must be able to manage time with technique of problem solving and time management". Problem solving and time management are suitable because 
both require students to have planning which is organized, consistent, purposeful and discipline in using time. In addition, techniques of problem solving can also train students to think critically in identifying problems, learning habit and finding solution to face problems.

\section{Difficulty Due to Irrelevant Learning Method}

The result of data analysis on English difficulty related to irrelevant learning method. It can be seen in the details on Table 7 .

Table 7. Difficulty Table Due to Irrelevant Learning Method

\begin{tabular}{llccc}
\hline No & Answer Options & $\begin{array}{c}\text { Fre- } \\
\text { quency }\end{array}$ & Value & $(\%)$ \\
\hline 1. & Very Problematic & 7 & 7 & 8 \\
2. & Problematic & 25 & 50 & 29 \\
3. & Quite Problematic & 31 & 93 & 37 \\
4. & No problem & 22 & 88 & 26 \\
& $\quad$ Total & 85 & 238 & 100 \\
\hline
\end{tabular}

Total value is $238=$ Quite Problematic Value percentage index 238: $340 \times 100 \%=$ $70 \%$

The result of data processing on Table 7 obtained the level of difficulty experienced by students due to the irrelevant learning method is at $70 \%$. This percentage of difficulty level is categorized as quite problematic, so it needs a solution to overcome this problem.

According to Wilson, Copeland Solas, \& Guthrie-Dixon (2016) stated that for relevant learning method, use Mind Map. Mind Map is suitable because it can open the potential of the human brain regarding words, images, numbers, logics, rhythms, colors, spatial awareness in a unique way so that students can improve their language skill. Another learning method that can be used to improve students learning is using interactive $\mathrm{CD}$ in improving learning student result $\mathrm{n}$ effectively and cognitively (Surjono \& Susila, 2013)

\section{Difficulty Due to Lack of Self-Confidence}

The result of data analysis on English difficulty related to lack of self-confidence. It can be seen in the details on Table 8 .
Table 8. Difficulty Table Due to Lack of Self-Convidence

\begin{tabular}{llccc}
\hline No & Answer Options & $\begin{array}{c}\text { Fre- } \\
\text { quency }\end{array}$ & Value & $(\%)$ \\
\hline 1. & Very Problematic & 18 & 18 & 21 \\
2. & Problematic & 21 & 42 & 25 \\
3. & Quite Problematic & 36 & 108 & 42 \\
4. & No problem & 10 & 40 & 12 \\
& $\quad$ Total & 85 & 208 & 100 \\
\hline
\end{tabular}

Total value is $208=$ Problematic

Value percentage index 208: $340 \times 100 \%=$ $61 \%$

The result of data processing on Table 8 found the level of difficulty experienced by students due to the lack of self-confidence of students in communicating English at number $61 \%$. This level of difficulty is categorized on the problematic level. So, a solution is needed to overcome this problem. Therefore, a special community is needed for students to exchange ideas and communicate each other with English in order to create self-confidence. This is also supported by expert opinion.

According to Deswarni (2017) to increase self-confidence, students must do regeneration". By entering this cadre, students are required to participate in it. From this matter, students usually exchange ideas, convey ideas or find solutions to solve problems so that it can increase social interaction and can train and be able to launch their communication.

\section{Difficulty Due to Constraints By Grammar When Arranging Words}

The result of data analysis on English language difficulty related to constraint by grammar can be seen in the details on Table 9.

The result of data processing on Table 9 obtained the level of difficulty experienced by students due to being constraint by grammar in arranging English words is at $61 \%$. This level of difficulty is categorized as the problematic level. Therefore, it is better for students who are not belonging to English study programs to be better not too focus on the grammar. It limits the students at the beginner level in communicating English. 
Table 9. Difficulty Table due to Constraint by Grammar When Arranging Words

\begin{tabular}{llccc}
\hline No & $\begin{array}{l}\text { Answer } \\
\text { Options }\end{array}$ & $\begin{array}{c}\text { Fre- } \\
\text { quency }\end{array}$ & Value & $(\%)$ \\
\hline 1. & Very Problematic & 10 & 10 & 12 \\
2. & Problematic & 33 & 66 & 39 \\
3. & Quite Problematic & 35 & 105 & 41 \\
4. & No problem & 7 & 28 & 8 \\
& $\quad$ Total & 85 & 209 & 100 \\
\hline
\end{tabular}

Total value is $209=$ Problem

Value percentage index 209: $340 \times 100 \%=$ $61 \%$.

\section{Difficulty Due to Lack of Willingness in Learning English}

The result of data analysis on English difficulty related to lack of willingness in learning English can be seen in the details on Table 10

Table 10. Difficulty Table Due to Lack of Willingness in Learning English

\begin{tabular}{clccc}
\hline No & Answer Options & $\begin{array}{c}\text { Fre- } \\
\text { quency }\end{array}$ & Value & $(\%)$ \\
\hline 1. & Very Problematic & 6 & 6 & 7 \\
2. & Problematic & 17 & 34 & 20 \\
3. & Quite Problematic & 27 & 81 & 32 \\
4. & No problem & 35 & 140 & 41 \\
& $\quad$ Total & 85 & 261 & 100 \\
\hline
\end{tabular}

Total value is $261=$ Quite Problematic Value percentage index 261: $340 \times 100 \%=$ $77 \%$

The result of data processing on Table 10 found the level of difficulty experienced by students due to lack of willingness in learning English is at $77 \%$. It is categorized as quite problematic. The result of this percentage of difficulty level indicates that students' willingness or intention to learn English is very low.

\section{Difficulty Due to Fast Bored}

The result of data analysis on English difficulty due to fast bored can be seen in the details on Table 11.
Table 11. Difficulty table Due to Fast Bored

\begin{tabular}{clccc}
\hline No & Answer Options & $\begin{array}{c}\text { Fre- } \\
\text { quency }\end{array}$ & Value & $(\%)$ \\
\hline 1 & Very Problematic & 6 & 6 & 7 \\
2 & Problematic & 16 & 32 & 19 \\
3 & Very Problematic & 35 & 105 & 41 \\
4 & Problematic & 23 & 92 & 27 \\
& Total & 85 & 240 & 100 \\
\hline
\end{tabular}

Total value is $252=$ Sufficient Problems

Value percentage index 252: $340 \times 100 \%=$ $74 \%$

The result of data processing on Table 11 found the level of difficulty experienced by students due to fast bored in learning English is at a percentage of $74 \%$ which is categorized as quite problematic. The result of this percentage of difficulty level indicates that students' willingness or intention to learn English is very low.

\section{Difficulty Due to No Supporting Facilities}

The result of data analysis on English difficulty related to no supporting facilities can be seen in the details in Table 4.10

Table 12. Difficulty Table Due to No Supporting Facilities

\begin{tabular}{llccc}
\hline No & Choice Answer & $\begin{array}{c}\text { Fre- } \\
\text { quency }\end{array}$ & Value & $(\%)$ \\
\hline 1. & Very Problematic & 11 & 11 & 13 \\
2. & Problematic & 16 & 32 & 19 \\
3. & Quite Problematic & 35 & 105 & 41 \\
4. & No problem & 23 & 92 & 27 \\
& $\quad$ Total & 85 & 240 & 100 \\
\hline
\end{tabular}

Total Value is $240=$ Quite Problems Value percentage index 240: $340 \times 100 \%=$ $71 \%$

The result of data processing on Table 12 obtained the level of difficulty experienced by students because there are no supporting facilities that support them in learning English is at a percentage of $71 \%$ which is categorized quite problematic. The result of the percentage level of difficulty indicates that limited facilities in learning English are also factor that greatly influences their English communication skills. 


\section{The Results of Research Analysis}

The result of the descriptive quantitative research data that have been described can be seen that the difficulty level of information system students in communicating English is categorized at the level of Quite Problematic with the percentage index is $69 \%$.

The percentage results obtained from the total value of all questions related to the difficulties experienced by students when communicating in English. Data on all these difficulties can be summarized in Table 13 .

Table 13. Data of All Difficulties

\begin{tabular}{llc}
\hline No & Answer Options & Item Number \\
1. & Very Problematic & 86 \\
2. & Problematic & 470 \\
3. $\quad$ Quite Problematic & 999 \\
4. No problem & 784 \\
Total Value & 2339 \\
Total Value Max & 3400 \\
Index Percentage & $69 \%$ \\
Category & Quite Problematic \\
\hline
\end{tabular}

\section{CONCLUSION}

Based on the result of descriptive quantitative research data in this study can be concluded that the difficulty level of information system students in communicating English is categorized at the level of Quite Problematic with the percentage of difficulty level is $69 \%$.

\section{ACKNOWLEDGMENTS}

The researchers would like to convey thanks to the Amal Bakti Foundation and STMIK Indonesia Padang for the facilities and infrastructure in this study. Then, the researchers would also like to thank to the Chairperson of LPPM STMIK Indonesia as the responsible institution in the field of research and community service which accommodates this research with contract numbers 012/K.A/LPPM/STMIK-I/2018.

\section{REFERENCES}

Afisa, S. Y. P. (2015). The students'

difficulties in speaking at the tenth grade of SMA Negeri 1 Sine in 2014/2015 academic year. Skripsi. Muhammadiyah University of Surakarta.

Deswarni, D. (2017). The use of skit technique to increase students' selfconfidence in speaking. AL-ISHLAH: Jurnal Pendidikan, 9(2), 101-113. Retrieved from http://journal.staihubbulwathan.id/index. php/alishlah/article/view/53

Kustandi, C., \& Sutjipto, B. (2011). Media pembelajaran manual dan digital. Bogor: Ghalia Indonesia.

Megawati, F. (2016). Kesulitan mahasiswa dalam mencapai pembelajaran bahasa Inggris secara efektif. PEDAGOGIA: Jurnal Pendidikan, 5(2), 147. https://doi.org/10.21070/pedagogia.v5i2. 246

Mulyana, D. (2008). Imu komunikasi; suatu pengantar. Bandung: PT Remaja Rosdakarya.

Nugroho, Y. S., Nurkamto, J., \& Sulistyowati, H. (2012). Improving students' vocabulary mastery using flashcards. English Education; Jurnal Pendidikan Bahasa Inggris, 1(1), 1-15. Retrieved from http://jurnal.fkip.uns.ac.id/index.php/bhs _inggris/article/view/1240

Nurhidayati, D. D. (2016). Peningkatan pemahaman manajemen waktu melalui bimbingan kelompok dengan teknik problem solving pada siswa. PSIKOPEDAGOGIA Jurnal Bimbingan Dan Konseling, 5(1), 24. https://doi.org/10.12928/psikopedagogia. v5i1.4592

Rohida, L. (2018). Pengaruh era revolusi industri 4.0 terhadap kompetensi sumber daya manusia. Jurnal Manajemen Dan Bisnis Indonesia, 6(1), 114-136. https://doi.org/10.31843/jmbi.v6i1.187

Siregar, S. (2017). Statistik parametrik untuk penelitian kuantitatif. Jakarta: Bumi Aksara.

Surjono, H. D., \& Susila, H. R. (2013). Pengembangan multimedia pembelajaran bahasa inggris untuk 
SMK. Jurnal Pendidikan Vokasi, 3, 45. https://doi.org/http://dx.doi.org/10.21831 /jpv.v3i1.1576

Wilson, K., Copeland Solas, E., \& GuthrieDixon, N. (2016). A preliminary study on the use of mind mapping as a visuallearning strategy, in general education science classes for Arabic speakers in the United Arab Emirates. Journal of the Scholarship of Teaching and Learning, 16(1), 31. https://doi.org/10.14434/josotl.v16i1.191 81

Zahroh, S. M., \& Sudira, P. (2014). Pengembangan perangkat pembelajaran keterampilan generik komunikasi negosiasi siswa SMK dengan metode 4D. Jurnal Pendidikan Vokasi, 4(3), 379390.

https://doi.org/10.21831/jpv.v4i3.2561 